\title{
Microsomal Prostaglandin E Synthase
} Family

National Cancer Institute

\section{Source}

National Cancer Institute. Microsomal Prostaglandin E Synthase Family. NCI Thesaurus.

Code C129435.

A family of membrane bound enzymes that catalyze the biosynthesis of prostaglandin E2 from prostaglandin $\mathrm{H} 2$. 